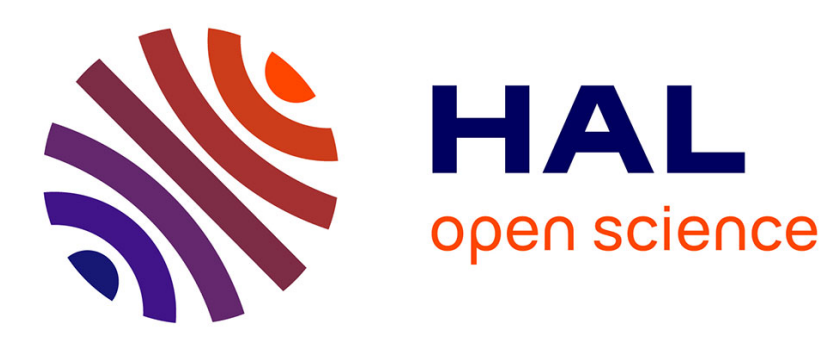

\title{
Inhibition of calcium carbonate precipitation by aqueous extract of Paronychia argentea
}

Zineb Belarbi, Jean Gamby, Laid Makhloufi, Bruno Sotta, Bernard Tribollet

\section{To cite this version:}

Zineb Belarbi, Jean Gamby, Laid Makhloufi, Bruno Sotta, Bernard Tribollet. Inhibition of calcium carbonate precipitation by aqueous extract of Paronychia argentea. Journal of Crystal Growth, 2014, 386, pp.208-214. 10.1016/j.jcrysgro.2013.09.048 . hal-00944045

\section{HAL Id: hal-00944045 \\ https: / hal.sorbonne-universite.fr/hal-00944045}

Submitted on 4 Nov 2014

HAL is a multi-disciplinary open access archive for the deposit and dissemination of scientific research documents, whether they are published or not. The documents may come from teaching and research institutions in France or abroad, or from public or private research centers.
L'archive ouverte pluridisciplinaire HAL, est destinée au dépôt et à la diffusion de documents scientifiques de niveau recherche, publiés ou non, émanant des établissements d'enseignement et de recherche français ou étrangers, des laboratoires publics ou privés. 


\title{
Inhibition of calcium carbonate precipitation by aqueous extract of Paronychia Argentea
}

\author{
Zineb Belarbi ${ }^{\mathrm{a}, \mathrm{b}}$, Jean Gamby ${ }^{\mathrm{a},{ }^{,}}$, Laid Makhloufi ${ }^{\mathrm{b}}$, Bruno Sotta ${ }^{\mathrm{c}}$, Bernard Tribollet ${ }^{\mathrm{a}}$ \\ ${ }^{a}$ Laboratoire Interfaces et Systèmes Electrochimiques, UPR 15 CNRS, case courrier 133, Université \\ Pierre et Marie Curie, Paris 6, 4 Place Jussieu, 75252, Paris cedex 05, France. \\ ${ }^{b}$ Laboratoire d'Electrochimie, Corrosion et de Valorisation Energétique (LECVE) \\ Faculté de Technologie, Université A. MIRA - Béjaia (06000), Algérie \\ ${ }^{c}$ UPMC, UR 5, Laboratoire de Physiologie cellulaire et Moléculaire des Plantes, Université Pierre et \\ Marie Curie, Paris 6, 4 Place Jussieu, 75252, Paris cedex 05, France.
}

* Corresponding author: jean.gamby@upmc.fr Tel: +33 1442736 40; Fax: +33 14427 4074; 


\begin{abstract}
This paper focuses on the development of a new green inhibitor "aqueous extract of Paronychia Argentea" for reducing calcium carbonate scale formation on metallic surfaces. The effects of temperature and biocides on the efficiency of the inhibitor were investigated. Its antiscaling properties have been evaluated by chronoamperometry method and the calcareous layers were characterized by scanning electron microscopy observations. A complete scaling inhibition was obtained with a concentration of $70 \mathrm{ppm}$ of green inhibitor for calcocarbonically pure water at $20^{\circ} \mathrm{C}$ and $45^{\circ} \mathrm{C}$. However, its efficiency was decreased at $60^{\circ} \mathrm{C}$. Different commercially available biocides named B310, B320, B330 and B340 were also tested. The biocide B340 was the only found not compatible with green inhibitor.
\end{abstract}

Keywords: Calcium carbonate, Green inhibitor, Antiscalant, Biocide, Paronychia argentea. 


\section{INTRODUCTION}

Increasing environmental concerns and discharge limitations have imposed additional challenges in treating process waters. Thus, the concept of "Green Chemistry" was proposed and green scale inhibitors became a focus of water treatment technology. Finding some economical and environmentally friendly inhibitors is one of the major research focuses nowadays. Scaling in natural hard water is a major concern in different fields of industrial processes and domestic installations. Undesirable scale deposits often cause numerous technical and economical problems such as total or partial obstruction of pipes leading to a decrease in flow rate; reduced heat transfer as calcium carbonate precipitate is 15 to 30 times less conductive than steel; seizure of valves and clogging of filters, etc. In nuclear power plants, the power produced is often limited by scaling in cooling towers. The scale induced corrosion especially in cooling water systems [1]. This scale formation is the result of changes in the ionic composition, $\mathrm{pH}$, pressure and temperature of the brine.

To solve scaling problems, several processes can be recommended, particularly the addition of chemical inhibitors. Indeed, the addition in water prevents scale formation even if very small concentrations are added. It can affect the nucleation and crystallization rates of $\mathrm{CaCO}_{3}$ and induce morphological changes of the crystal shape. [2]. Inhibitors commonly used in the industry include phosphates and polyphosphates, phosphate esters, organic phosphonates, polyacrylates, and various other polymers and copolymers of phosphonates, carboxylates, and sulfonates [2]. The efficiency of phosphorous and nitrogen compounds against scale formation has already been demonstrated [3, 4]. However, the use of such compounds generates a modification of the biological cycle. As reported by Camargo et al. Inhibitors are toxic to the environment and the health. In the case of the bacterial flora, they can act as disturbers of the ecosystem. One can cite the case of eutrophication, one of the most dramatic 
consequences is the deoxygenation of the water that leading to the death of aquatic organisms $[5]$.

Researches are in progress for new inhibiting formulations that must be compatible with the environment usually named "green inhibitors". A chemical is defined as "green" according to three criteria: toxicity, bioaccumulation and biodegradation [6-8].

The effects of scale inhibitors on calcareous deposit have been studied mostly by forming scale from a supersaturated scaling solution and by doing chemical analyses [9-11], microscopic analyses [12], spectroscopic analyses [3,12], tube blocking tests [13], turbidity [14] or $\mathrm{pH}$ measurements [4].

In the present study a novel green inhibitor, an aqueous extract of Paronychia Argentea, was prepared and tested to this aim. In order to understand the interactions occurring between the inhibitors and the surface, electrochemical measurement (chronoamperometry) together with scanning electron microscopy (SEM) were used for investigating the efficiency of Paronychia Argentea aqueous extract on the inhibition of calcium carbonate deposition on a metallic surface. The combined effect of water temperature and inhibitor concentration was also taken into an account.

Paronychia Argentea (PA) is a perennial plant, 30-50 cm high and widely distributed in Mediterranean area. The leaves, up to $2 \mathrm{~mm}$ long and $5 \mathrm{~mm}$ broad, are not hairy, linear lanceolate and sometimes ovate with acute tips. Flower heads lateral and terminal, dense, intermixed with leaves. Flowering time is from January to April [15]. The aerial parts of Paronychia Argentea are used in traditional medicine in Algeria to treat kidney stones [16]. Paronychia Argentea reported to contain the flavonoids phenolics and terpenoids [17]. However, no study has so far been published about the scaling inhibitive effects of Paronychia Argentea aqueous extract. Moroever, Bouanani et al. described the effects of two extracts of Paronychia argentea was evaluated. They demonstrated that the acute and sub 
acute toxicity after oral administration of Paronychia argentea extracts did not induce significant alterations in almost all biochemical, haematological and morphological parameters in Wistar rats [18].

\section{Experimental procedure}

\subsection{Plant material}

Aerial parts of Paronychia Argentea (PA) were collected in April 2008 from Ighil Ali City in the north east of Algeria. The plant was identified by the Botany Laboratory of Bejaia University.

\subsection{Preparations of plant extract}

The dried leaves and flowers of PA were coarsely powdered and extracted by adding $100 \mathrm{ml}$ of boiling distilled water to $20 \mathrm{~g}$ of PA and leaving them for 15 minutes to infuse. The infusion at $20 \%(\mathrm{w} / \mathrm{vol})$ was then strained through a microfilter with a pore size of $0.20 \mu \mathrm{m}$ and subjected to electrochemical tests.

\subsection{Characterization of Biocides}

Biocides were used to remove microbial growth in water. The choice of a biocide formulation was based on various factors such as compatibility with scale inhibitors. For this purpose, we studied the compatibility of various industrial biocides during PA inhibition tests. All these biocides arise from Odyssée Environnement (Requeil, France) for which exact composition was not communicated. However, the key active ingredient in the composition of each biocide is shown in the table 1.

\subsection{Electrochemical Measurements}

The chronoamperometry method is used in this work [19]. It consists to precipitate calcium carbonate on metal surface at cathodic potential (-1V vs SCE). The applied potential promotes the $\mathrm{O}_{2}$ reduction according to the following electrochemical reaction:

$$
\mathrm{O}_{2}+2 \mathrm{H}_{2} \mathrm{O}+4 e^{-} \rightarrow 4 \mathrm{OH}^{-}
$$


The production of hydroxide ions in the vicinity of the electrode, from $\mathrm{O}_{2}$ reduction increases the local $\mathrm{pH}[20]$ and forces calcium carbonate to precipitate in a solid crystalline phase according to the chemicals reactions:

$$
\begin{aligned}
& \mathrm{HCO}_{3}^{-}+\mathrm{OH}^{-} \Leftrightarrow \mathrm{CO}_{3}^{2-}+\mathrm{H}_{2} \mathrm{O} \text { (in bulk) } \\
& \mathrm{Ca}^{2+}+\mathrm{CO}_{3}^{2-} \Leftrightarrow \mathrm{CaCO}_{3} \text { (at the interface) }
\end{aligned}
$$

All electrochemical measurements were performed with a three-electrode cell. The working electrode was a copper rotating disk electrode (RDE) of $5 \mathrm{~mm}$ diameter; its rotation speed was fixed to $500 \mathrm{rpm}$. The counter electrode was a large platinum grid, and potentials were measured against a saturated calomel electrode (SCE). Electrochemical experiments were driven under potentiostatic conditions using RADIOMETRE PGP 201 interface (Potentiostat/Galvanostat). A computer provided with a Windows software application (Voltamaster1) was used.

The solution was a calcocarbonically pure water (CCP) obtained by dissolving $\mathrm{CaCO}_{3}$ in deionised water, the concentration of $\mathrm{Ca}^{2+}$ was $120 \mathrm{mg} \mathrm{L}^{-1}$. The working $\mathrm{pH}$ is fixed at 5.8. For that, the $\mathrm{pH}$ was continuously controlled by using a $\mathrm{pH}$ meter and was adjusted by bubbling $\mathrm{CO}_{2}$ gas at the surpersaturation value. The solution was thermostated at $20^{\circ} \mathrm{C}$. The electrochemical test was performed over 150 minutes. At each test end, the sample was rinsed with bidistilled water and dry with nitrogen gas. The deposit morphology was observed using scanning electron microscopy (SEM). The SEM analyze was performed with a FEI Company Quanta 200 microscope.

\section{Results and discussion}

\subsection{Optimization of scale inhibitors content}

Various concentration of aqueous extract of PA were introduced in an electrochemical cell for chronoamperometry measurement. Fig. 1 shows the chronoamperometric curves obtained for an applied potential of $-1 \mathrm{~V}$ versus SCE in absence (blank) or in presence of PA aqueous 
extract. The $\mathrm{Cu}$ electrode rotation speed was fixed at $500 \mathrm{rpm}$. The measured current is the limiting diffusion current of the oxygen reduction while water reduction current is negligible at $-1 \mathrm{~V} / \mathrm{SCE}$ (see Fig. S1 and Fig. S2 in the supplementary material). The blank experiment in

Fig. 1 (curve a), displayed a typical CA curve where the reduction current of the dissolved oxygen decreases with respect to time due to the blocking effect of the $\mathrm{CaCO}_{3}$ deposit, it promotes a physical barrier against oxygen diffusion. However, a residual value of current was obtained even though the electrode surface was considered as totally blocked. This is due to oxygen diffusion through interstices that exist between calcite blocks at long immersion time. In this case, the convection is neglected in the pores and the oxygen transport (in the pores) is governed by diffusion [21]. In the presence PA aqueous extract, the CA curves b-d (Fig. 1) are not the same shape than the one obtained with the blank (curve (a)). Indeed, the cathodic current decreases remaining relatively stable at a long immersion time and not tend to a residual value . According to Fig. 1, an optimum concentration of $70 \mathrm{ppm}$ seems to be more efficient for $\mathrm{CaCO}_{3}$ inhibition.

\subsection{Characterization of scales}

SEM micrographs were carried out for the various deposits formed in the absence and in the presence of PA. They correspond to the experiment end (about $150 \mathrm{~min}$ ) of deposition indicated by CA curves discussed above and shown in Fig. 1. The SEM micrograph for the control experiment displayed in Fig. 2, shows two forms of crystals. The first kind corresponds to of cubic crystals where a typical calcite form can be seen, which is one of the three allotropic forms of $\mathrm{CaCO}_{3}$ [22-24]. The second kind corresponds to vaterite with flattened volcanoes. The allotropic forms were identified by using EDS and XRD analysis (see Fig. S3 and Fig. S4 in the supplementary material, respectively). In the presence of PA aqueous extract, the optimum concentration of $70 \mathrm{ppm}$ was added to the CCP water. In the presence $70 \mathrm{ppm}$ of PA, the SEM micrographs (Fig. 3b) show the different depths of the 
mechanical polishing lines on the substrate surface. In agreement with the electrochemical results (Fig. 1), no scale was detected on the electrode surface confirming accessibility of the surface area. In the presence $35 \mathrm{ppm}$ and $140 \mathrm{ppm}$ of PA added to the CCP water, few small particles of crystal are observed on the electrode surface, as displayed in Fig. 3a and 3c, respectively. The crystal deposition is inhibited on the surface area as Paronychia Argentea extract concentrations increases until the optimum value of $70 \mathrm{ppm}$. For lower concentrations, calcite and vaterite crystals are highly deformed and cannot be distinguished exactly. This morphology probably changes due to a partial covering of the crystal surface by the inhibitor [25]. Calcium carbonate crystallization consists of two stages: nucleation and growth. The adsorbed molecules of antiscalant were presumed to inhibit scale formation by interfering with the two processes involved in crystal formation at the interface metal/ solution.

\subsection{Temperature effect}

In absence of inhibitor (control experiment), the effect of temperature is obvious: calcium carbonate precipitation is accelerated at higher temperatures $\left(45^{\circ} \mathrm{C}\right.$ and $\left.60^{\circ} \mathrm{C}\right)$ and decreased at a low temperature $\left(20^{\circ} \mathrm{C}\right)$. The curves shape obtained (Fig. 4a) confirmed the favorable role of temperature upon calcareous deposition. As described in the literature, the temperature decreases the solubility of dissolved oxygen $[26,27]$ and increases the diffusion coefficient [27]. This latter induces an increase of cathodic current of oxygen reduction (equation 1) [28]. As observed in fig. $4 \mathrm{a}$, the initial current is higher when temperature increases from $20^{\circ} \mathrm{C}$ to $60^{\circ} \mathrm{C}$. For $45^{\circ} \mathrm{C}$ and $60^{\circ} \mathrm{C}$ the cathodic current decreases abruptly from 10 minutes of immersion time until reaching a residual value characteristic to blocked surface.

In fig. $4 \mathrm{~b}$, the same experiments were realized with the optimum concentration of $70 \mathrm{ppm}$ in order to investigate PA aqueous extract efficiency depending on temperature. The same behaviour is observed for the initial current which is more higher when temperature increases. However, for long immersion time the PA aqueous extract is less efficient because the 
cathodic current starts to decrease from 30 minutes for both higher temperature: $45^{\circ} \mathrm{C}$ to $60^{\circ} \mathrm{C}$. The SEM micrographies displayed in Fig.5a and $5 \mathrm{~b}$ confirm that the electrode surface is not covered by scale. That is confirmed by EDS analysis where calcium element is absent. In contrast, Fig. 5c shows that electrode surface is recovered by a layer where the morphology is different from typical $\mathrm{CaCO}_{3}$ layer (Fig. 2). The EDS analysis indicates the presence of calcium in this layer (see Fig S5 in the supplementary material). These results allow to conclude that PA aqueous extract is not efficient at $60^{\circ} \mathrm{C}$ and we can supposed that the temperature and the inhibitor influence the kinetics of the scale deposition leading to a degenerated layer.

\section{4 Effect of biocides on the inhibition efficiency}

In order to investigate the compatibility of PA aqueous extract in presence of commercial biocides, experiments were doing with the obtained optimum concentration. Fig. 6 shows the

obtained chronoamperometric curves with addition of $70 \mathrm{ppm}$ PA in presence of $0.1 \mathrm{~mL} . \mathrm{L}^{-1}$ biocide. The experiment is reproduced for each biocide presented in table 1 Chronoamperometric curves obtained at long immersion time (24h) with and without biocides have the same shape (Fig.6). The residual cathodic current tends to $-20 \mu$ A. The SEM micrographies displayed in Fig. 7 take in evidence no interference of biocides B310 B320 B330 on the way of PA aqueous extract interacts on scale inhibition except for B340 where scale is present.

\section{Conclusion}

The obtained data take in evidence that Paronychia Argentea aqueous extract was succesfully tested for preventing scale deposition on copper. A concentration level of $70 \mathrm{ppm}$ was found as an optimal concentration in calcocarbonically pure water at $20^{\circ} \mathrm{C}$ and $45^{\circ} \mathrm{C}$ but its efficiency was decreased at $60^{\circ} \mathrm{C}$. The extract can be used as a good antiscalant. The action mode of PA aqueous extract and the temperature on scale inhibition are under process for a 
better understanding of the mechanism. Different biocides B310, B320, and B330 were found compatible with PA aqueous extract except for dibromonitrilopropionamide-2-butoxyethanol (B340) where interaction with the inhibitor is probably involved. 


\section{Acknowledgments}

We thank Amel Ben Amor and Madani Mamass at the "University A. Mira Bejaia" and Françoise Pillier at the "Laboratoire Interfaces et Systèmes Electrochimiques - Université Pierre \& Marie Curie, UPMC'for technical assistance on SEM micrographs acquisition. The biocides were generously supplied by Odyssée Environnement. This research was supported by the French research organism "Institut de Recherche pour le développement" (IRD). 


\section{References}

[1] M. B. Tomson, Effect of precipitation inhibitors on calcium carbonate scale formation, J. Cryst. Growth. 62 (1983) 106-112.

[2] J. M. Matty, M. B. Tomson, Effect of multiple precipitation inhibitors on calcium carbonate nucleation, Appl. Geochem. 3 (1988) 549-556.

[3] T. Chen, A. Neville, K. Sorbie, Z. Zhong, Using in situ synchrotron radiation wide angle X-ray scattering (WAXS) to study $\mathrm{CaCO} 3$ scale formation at ambient and elevated temperature, Faraday Discuss. 136, (2007) 355-365.

[4] K. J. Westin, A.C. Rasmuson, Crystal growth of aragonite and calcite in presence of citric acid, EDTA and pyromellitic acid, J. Colloid Interface Sci. 282 (2005) 359-369.

[5] J. A. Camargo, A. Alonso, Ecological and toxicological effects of inorganic nitrogen pollution in aquatic ecosystems: a global assessment, Environment International 32 (2006) 831-849.

[6] P. T. Anastas, J.C. Warner, Green chemistry: Theory and practice.vol. 1, Oxford University press, New York, 1998.

[7] D. Darling, R. Rakshpal, Green chemistry applied to corrosion and scale inhibitors, Materials performance 37 (1998) 42-45.

[8] M. Thatcher, G. Payne, Impact of the OSPAR Decision on the Harmonised Mandatory control scheme on the offshore chemical supply industry, RSC \& EOSCA, Manchester, 2005. [9] R. J. Ross, K. C. Low, J. E. Shannon, Polyaspartate scale inhibitors-biodegradable alternatives to polyacrylates, Materials performance 36 (1997) 53-57.

[10] D. L. Verraest, J. A. Peters, H. Van Bekkum, G. M. Van Rosmale, Carboxymethyl inulin: a new inhibitor for calcium carbonate precipitation, J. Am. Oil. Chem. Soc. 73 (1996) $55-62$. 
[11] M.D. Yuan, E. Jamieson, P. Hammonds, B. Petrolite, Investigation of scaling and inhibition mechanisms and the influencing factors in static and dynamic inhibition tests. In: NACE Conference, Corrosion, Paper No. 67 (1998).

[12] H. Tong, W. Ma, L. Wang, P. Wan, J. Hu, L. Cao, Control over the crystal phase, shape, size and aggregation of calcium carbonate via a-aspartic acid inducing process, Biomaterials 25 (2004) 3923-3929.

[13] B. Bazin, N. Kohler, A. Zaitoun, T. Johnson, A new class of green mineral scale inhibitors for squeeze treatments. In: International Symposium on Oilfield Scale, SPE 87453, Aberdeen (2004).

[14] V. Tantayakom, T. Sreethawong, H. Scott Fogler, F.F. de Moraes, S. Chavadej, Scale inhibition study by turbidity measurement, J. Colloid Interface Sci. 284 (2005) 57-65.

[15] I. I. Hamdan, F.U. Afifi; Studies on the in vitro and in vivo hypoglycemic activities ofsome medicinal plants used in treatment of diabetes in Jordanian traditional medicine, J. Ethnopharmacology 93 (2004) 117-121.

[16] A. Beloued, Plantes médicinales d'Algérie, OPU, Alger, 1998.

[17] A. G. Al-Bakri, F. U. Afifi, Evaluation of antimicrobial activity of selected plant extracts by rapid XTT colorimetry and bacterial enumeration; J. Microbiol. Methods. 68 (2007) 1925.

[18] S. Bouanani, C. Henchiri, E. Migianu-Griffoni, N. Aouf, M. Lecouvey, Pharmacological and toxicological effects of Paronychia argentea in experimental calcium oxalate nephrolithiasis in rats, J. Ethnopharmacology 129 (2010) 38-45.

[19] F. Hui, J. Lédion, Evaluation methods for the scaling power of water; J. European of Water Quality, T.33, Fasc. 1 (2002). 
[20] C. Gabrielli, M. Keddam, H. Perrot, A Khalil, R. Rosset, M. Zidoune: Characterization of the efficiency of antiscale treatments of water -Part I: Chemical processes, J. Appl. Electrochem. 26 (1996) 1125-1132.

[21] Z. Belarbi, J. Gamby, L. Makhloufi, B. Tribollet. Nucleation-growth process of calcium carbonate on rotating disk electrode in mineral potable water, Electrochim. Acta. 109 (2013) 623-629.

[22] C. Deslouis, D. Festy, O. Gil, S. Touzain, B. Tribollet, Characterization of calcareous deposits in artificial sea water by impedance techniques-I. Deposit of $\mathrm{CaCO}_{3}$ without $\operatorname{Mg}(\mathrm{OH})_{2}$, Electrochim. Acta 43 (1998)1891-1901.

[23] C. Deslouis, A. Doncescu, D. Festy, O. Gil, V. Maillot, S. Touzain, B. Tribollet, Mater. Sci. Forum 1163 (1998) 289-292.

[24] Ch. Barchiche, C. Deslouis, D. Festy, O. Gil, Ph. Refait, S. Touzain, B. Tribollet, Characterization of calcareous deposits in artificial seawater by impedance techniques 3Deposit of $\mathrm{CaCO}_{3}$ in the presence of $\mathrm{Mg}(\mathrm{II})$, Electrochim. Acta. 48 (2003) 1645-1654.

[25] N. Abdel-Aal1, K. Sawada, Inhibition of adhesion and precipitation of $\mathrm{CaCO}_{3}$ by aminopolyphosphonate, J. Cryst. Growth. 256 (2003) 188-200.

[26] H. S. Ras, S. Ghizellaoui, Determination of anti-scale effect of hard water by test of electrodeposition, Procedia Engineering 33 (2012) 357 - 365.

[27] R. Ketrane, B. Saidani, O. Gil, L. Leleyter, F. Baraud, Efficiency of five scale inhibitors on calcium carbonate precipitation from hard water: effect of temperature and concentration, Desalination 249 (2009) 1397-1404.

[28] M. Zidoune, A. Khalil, P. Sakya, C. Colin, R. Rosset, Mise en évidence de l'effet antiincrustant de l'acide aminotris(méthylènephosphonique) par chronoampérométrie et chronoélectrogravimétrie, Electrochimie. C. R. Acad. Sci, 315 (2) (1992) 795-799. 


\section{Table Caption}

Table 1: Main characteristics of the commercial biocides used in this work. The essential component in the composition of commercial biocides is indicated. 


\section{Figure captions}

Fig. 1: Chronoamperometric curves obtained with different concentrations of aqueous extract of Paronychia Argentea at $20^{\circ} \mathrm{C}$ in CCP water containing $120 \mathrm{mg} \cdot \mathrm{L}^{-1}$ of calcium. The rotation speed of copper electrode is $\Omega=500 \mathrm{rpm}$, the applied potential is $E=-1 \mathrm{~V} / \mathrm{SCE}$.

Fig. 2: Calcium carbonates deposit obtained by electrodeposition after $150 \mathrm{~min}$ with no inhibitor. The rotation speed of copper electrode is $\Omega=500 \mathrm{rpm}$, the applied potential is $E=$ 1V/SCE.

Fig. 3: Calcium carbonates deposit obtained by electrodeposition after 150 min with various inhibitor concentration. 35,70 and $140 \mathrm{ppm}$. The rotation speed of copper electrode is $\Omega=$ $500 \mathrm{rpm}$, the applied potential is $E=-1 \mathrm{~V} / \mathrm{SCE}$.

Fig. 4: Chronoamperometric curves obtained with different temperatures $\left(20,45\right.$ and $\left.60^{\circ} \mathrm{C}\right)$ in CCP water containing $120 \mathrm{mg} . \mathrm{L}^{-1}$ of calcium. The rotation speed of copper electrode is $\Omega=500 \mathrm{rpm}$, the applied potential is $E=-1 \mathrm{~V} / \mathrm{SCE}$. a. In the absence of inhibitor. b. In the presence of inhibitor at $70 \mathrm{ppm}$.

Fig. 5: Scanning electron microscopy for scale obtained by electrodeposition after 150 minutes in CCP water with 70 ppm of inhibitor. a. $20^{\circ} \mathrm{C}$. b. $45^{\circ} \mathrm{C} . c .60^{\circ} \mathrm{C}$.

Fig.6: Chronoamperometric curves obtained with various biocides (B310, B320, B330 and B340) in CCP water containing $120 \mathrm{mg} . \mathrm{L}^{-1}$ of calcium at $20^{\circ} \mathrm{C}$ with $70 \mathrm{ppm}$ of inhibitor. The rotation speed of copper electrode is $\Omega=500 \mathrm{rpm}$, the applied potential is $E=-1 \mathrm{~V} / \mathrm{SCE}$.

Fig.7: : Scanning electron microscopy for scale obtained by electrodeposition in presence of mentioned biocides with 70 ppm of inhibitor after 24 hours of immersion. The rotation speed of copper electrode is $\Omega=500 \mathrm{rpm}$, the applied potential is $E=-1 \mathrm{~V} / \mathrm{SCE}$. a. In absence of inhibitor and without biocide (reference curve). b. In presence of inhibitor and without biocide. c. In presence of $70 \mathrm{ppm}$ of inhibitor and with $0.1 \mathrm{~mL} . \mathrm{L}^{-1}$ of biocide B310. d. In presence of $70 \mathrm{ppm}$ of inhibitor and with $0.1 \mathrm{~mL} \cdot \mathrm{L}^{-1}$ of biocide B320. e. In presence of $70 \mathrm{ppm}$ 
of inhibitor and with $0.1 \mathrm{~mL} . \mathrm{L}^{-1}$ of biocide B330. f. In presence of $70 \mathrm{ppm}$ of inhibitor and with $0.1 \mathrm{~mL} . \mathrm{L}^{-1}$ of biocide B340. 
Table1:

\begin{tabular}{|c|c|c|c|c|}
\hline Biocide & Odycide B310 & Odycide B320 & Odycide B330 & Odycide B340 \\
\hline Nature formula & Glutaraldehyde & $\begin{array}{c}\text { tetrakis(hydroxymethyl) } \\
\text { phosphonium sulfate }\end{array}$ & $\begin{array}{c}\text { 5-chloro-2-méthyl-2H- } \\
\text { isothiazole-3-one + 2-methyl- } \\
\text { 2H-isothiazole-3-one }\end{array}$ & $\begin{array}{c}\text { dibromonitrilopropion } \\
\text { amide2-butoxyethanol }\end{array}$ \\
$\begin{array}{c}\text { Density } \\
\text { pH }\end{array}$ & 1.07 & 1.05 & 1.06 & 3.4 \\
$\begin{array}{c}\text { Boiling point } \\
\text { Aspect and color }\end{array}$ & $\begin{array}{c}100^{\circ} \mathrm{C} \\
\text { colorless liquid } \\
\text { to yellowish } \\
\text { Action with water }\end{array}$ & $\begin{array}{c}100^{\circ} \mathrm{C} \\
\text { colorless liquid or } \\
\text { yellow } \\
\text { soluble }\end{array}$ & $\begin{array}{c}100^{\circ} \mathrm{C} \\
\text { colorless liquid or pale yellow }\end{array}$ & $\begin{array}{c}100^{\circ} \mathrm{C} \\
\text { colorless liquid to } \\
\text { amber } \\
\text { soluble }\end{array}$ \\
\hline
\end{tabular}


Fig. 1:

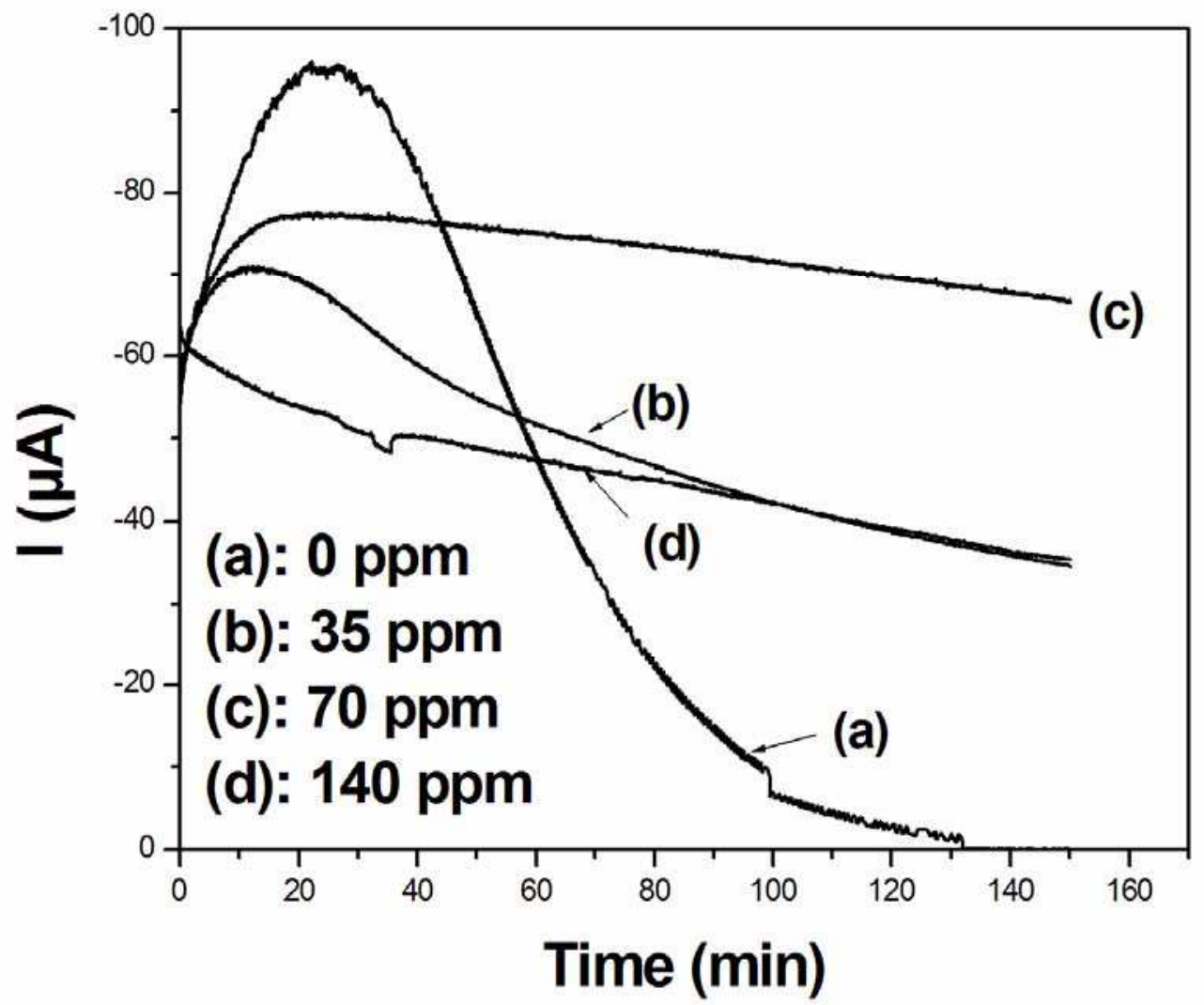


Fig. 2:
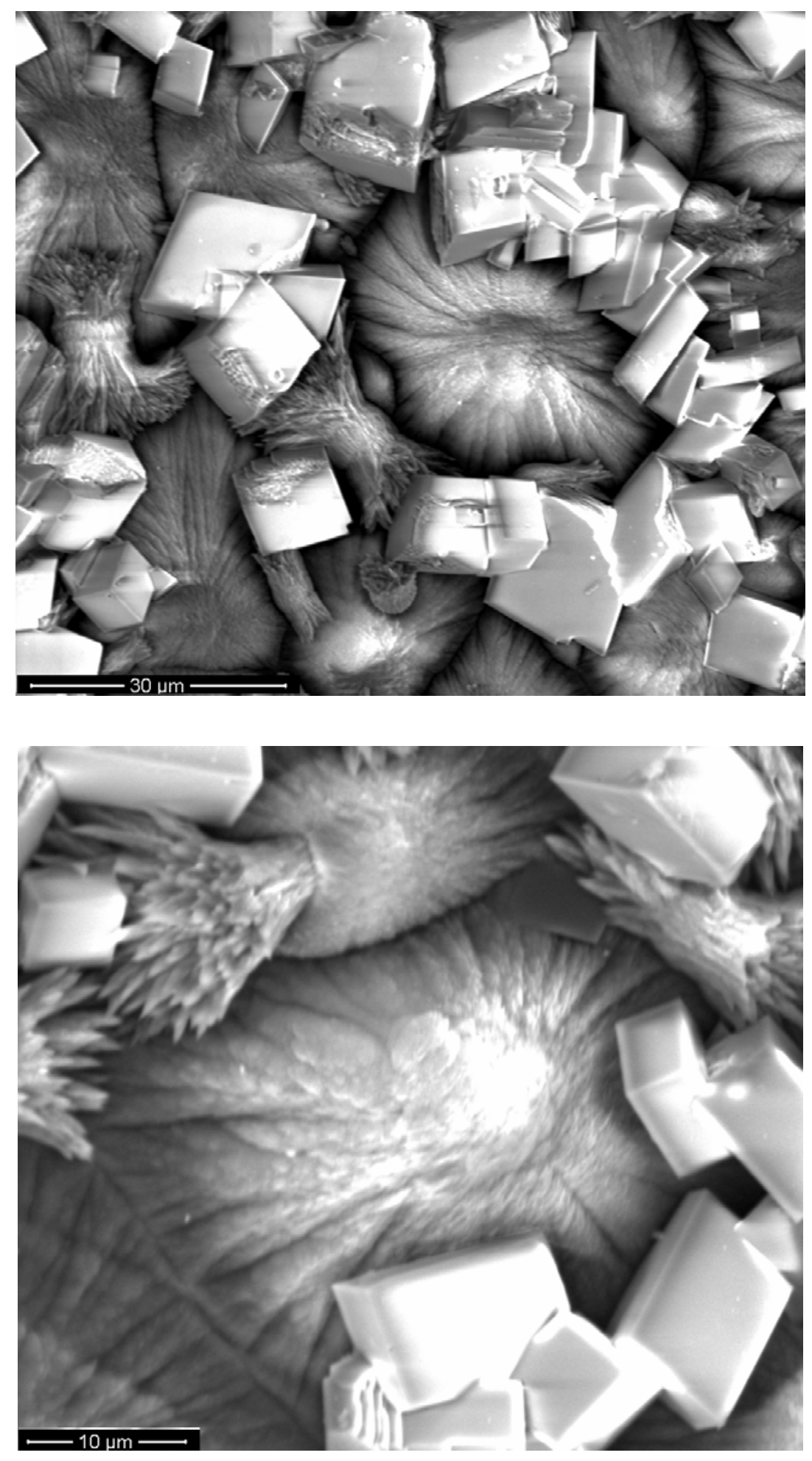
Fig. 3:
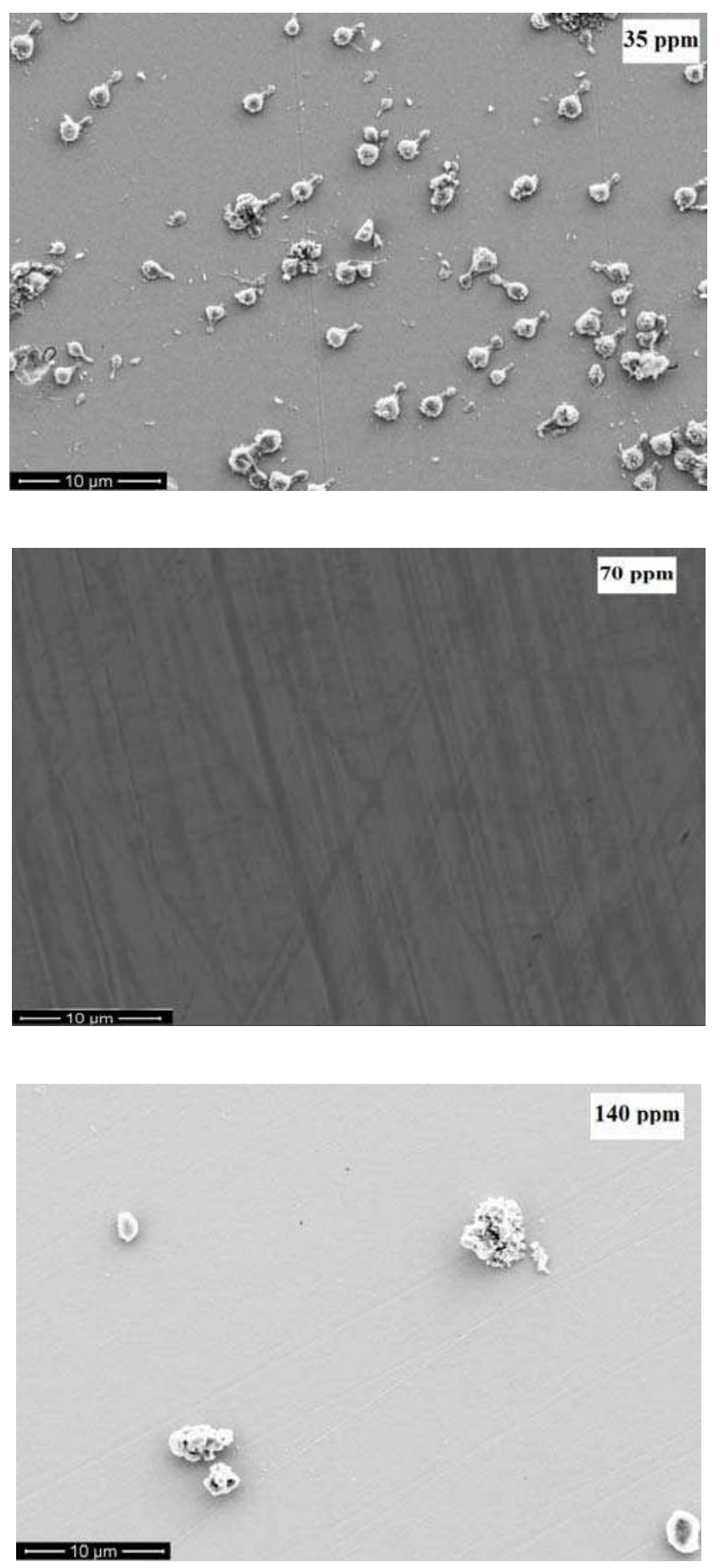
Fig. 4:

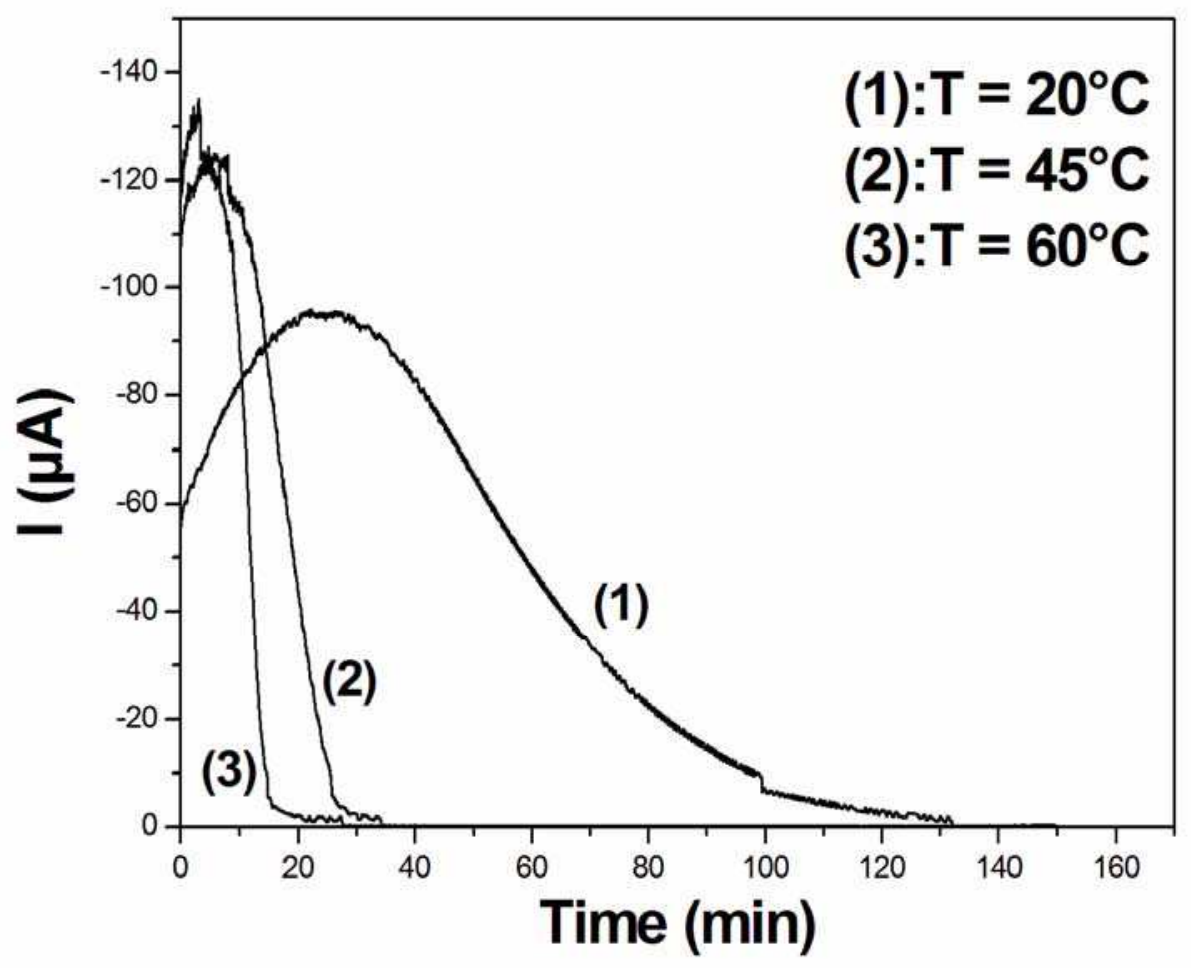

(a)

(b)

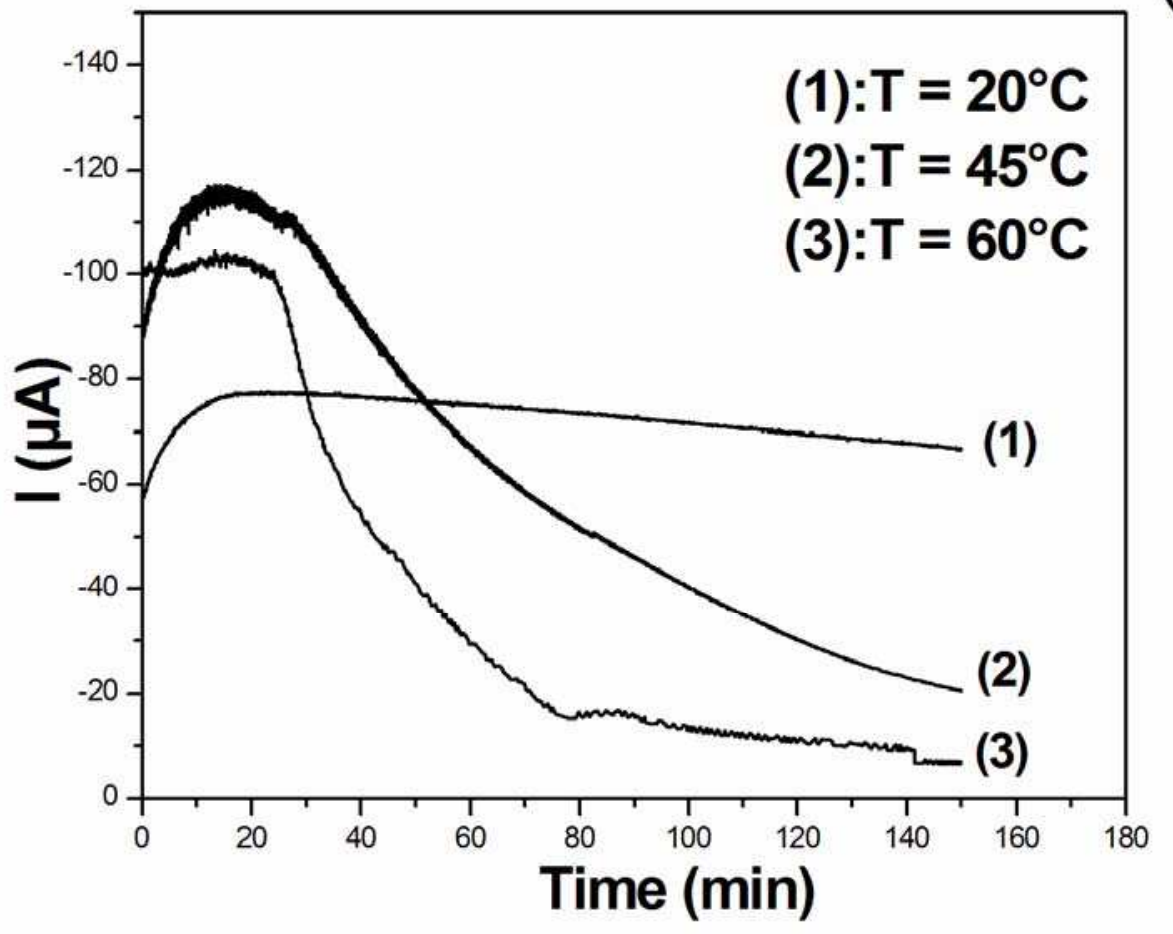


Fig.5:
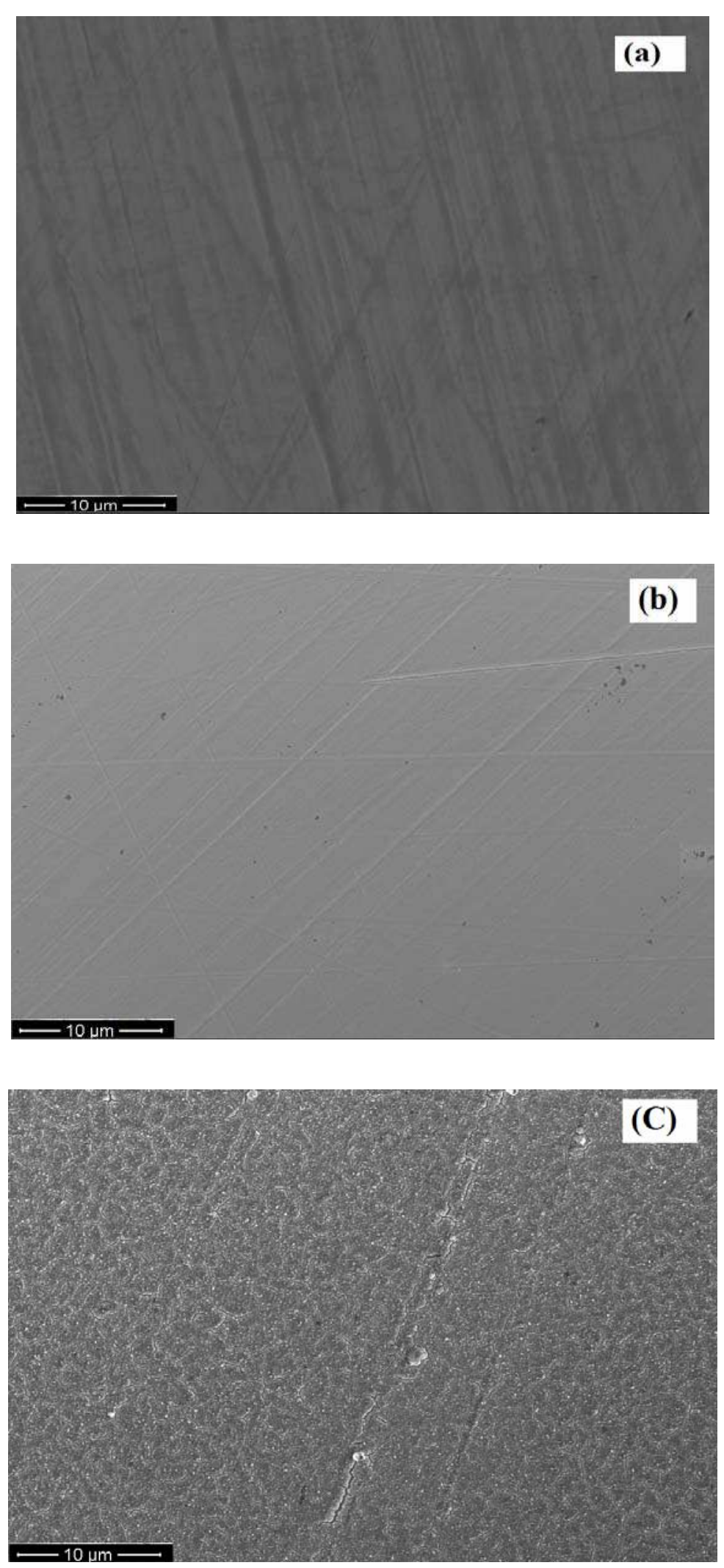
Fig. 6:

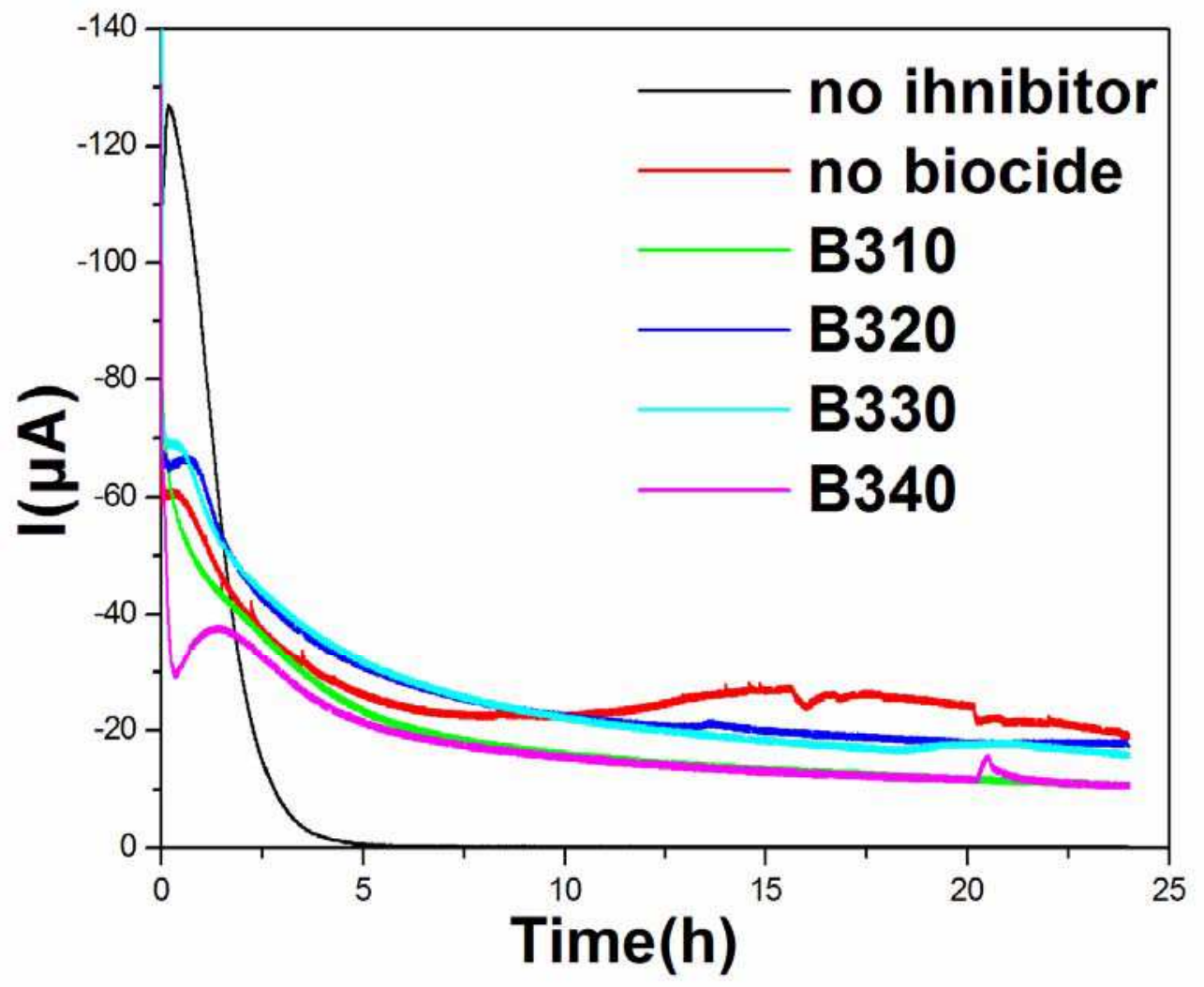


Fig. 7:
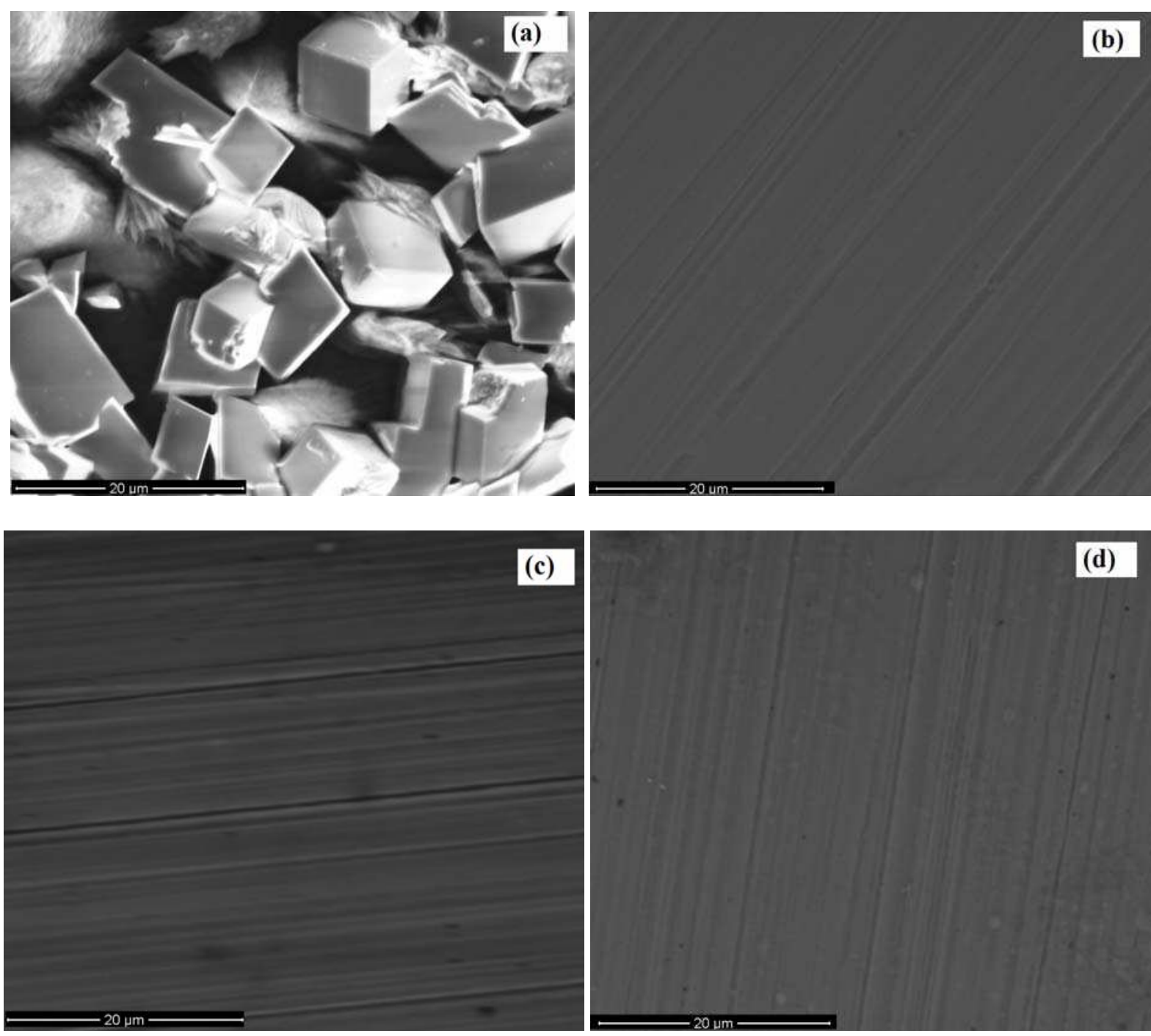

(d)

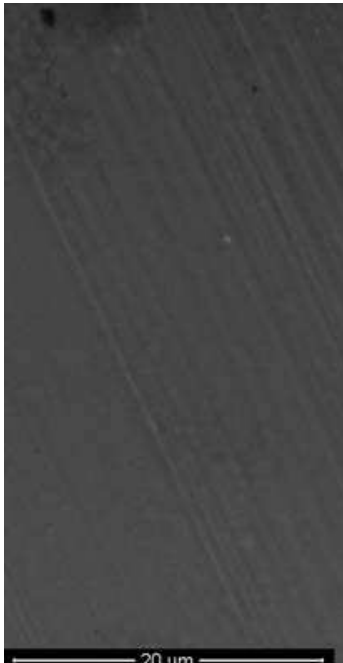

(e)

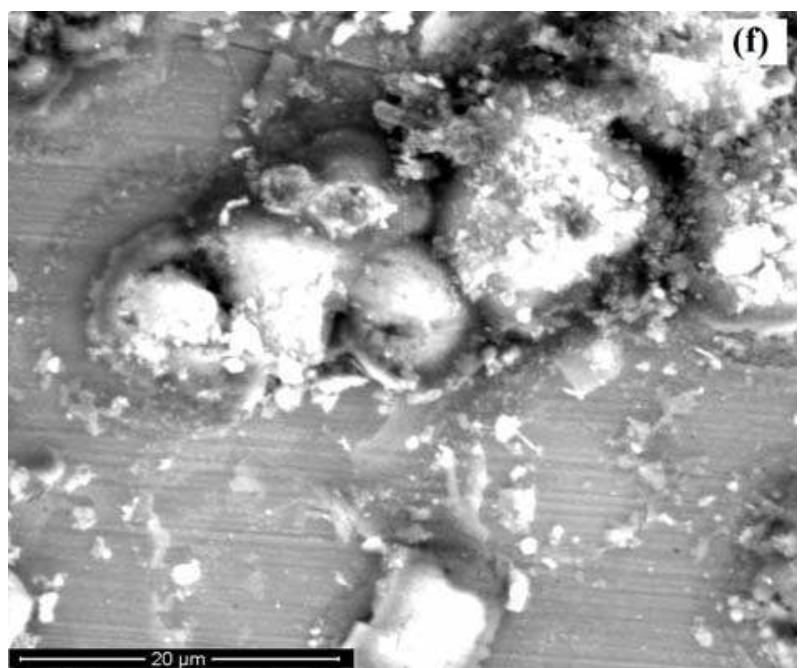

